\title{
The Significance of Recent Interest Rate Movements
}

\author{
by DENIS S. KARNOSKY
}

T HE ECONOMY is emerging from the slowdown of last year, which had resulted from monetary and fiscal actions taken in 1969 to reduce inflationary pressures. Economic activity began to recover last winter, but the expansion to date has been moderate, with the rates of inflation and unemployment remaining high. Some analysts have expressed dissatisfaction with the pace of recovery and skepticism about the prospects for real growth in the near future. Dissatisfaction centers on the continued sluggishness of employment growth. Contrary to the experience of other postwar recoveries, the rate of unemployment of the labor force remains at about the level reached at the bottom of the economic slump.

If the rate of unemployment is to be reduced, an accelerated growth of output is required. In questioning the prospects of achieving the necessary growth in the near future, some observers have mentioned the importance of preventing sharp increases in market interest rates. These analysts assert that, if the economic recovery is to have sound footing, interest rates must be kept from attaining the high levels of the past few years. According to this view, a return to "high" interest rates could lead to prohibitive borrowing costs which would run the risk of choking off new private demand.

These arguments ascribe rising interest rates to monetary stringency. They ignore, however, the continued strength of inflationary expectations. The recent rise in interest rates largely reflects strengthening demands for credit and the influence of persistent anticipations of further inflation. Instead of signaling restriction of the supply of credit, and thus portending a weakening economy, the recent interest rate movements are more indicative of the effect of rising aggregate demand and renewed inflationary pressures.

\section{Outline of the Expansion}

Total spending in the economy increased at a 7.8 per cent annual rate from the third quarter of 1970 to the second quarter of this year, translating into a 2.4 per cent rate of growth of real product and a 5.2 per cent rate of increase in prices. ${ }^{1}$ In the previous year total spending had increased 4.6 per cent, but all of the expansion reflected rising prices as the volume of goods and services produced declined about one-half per cent.

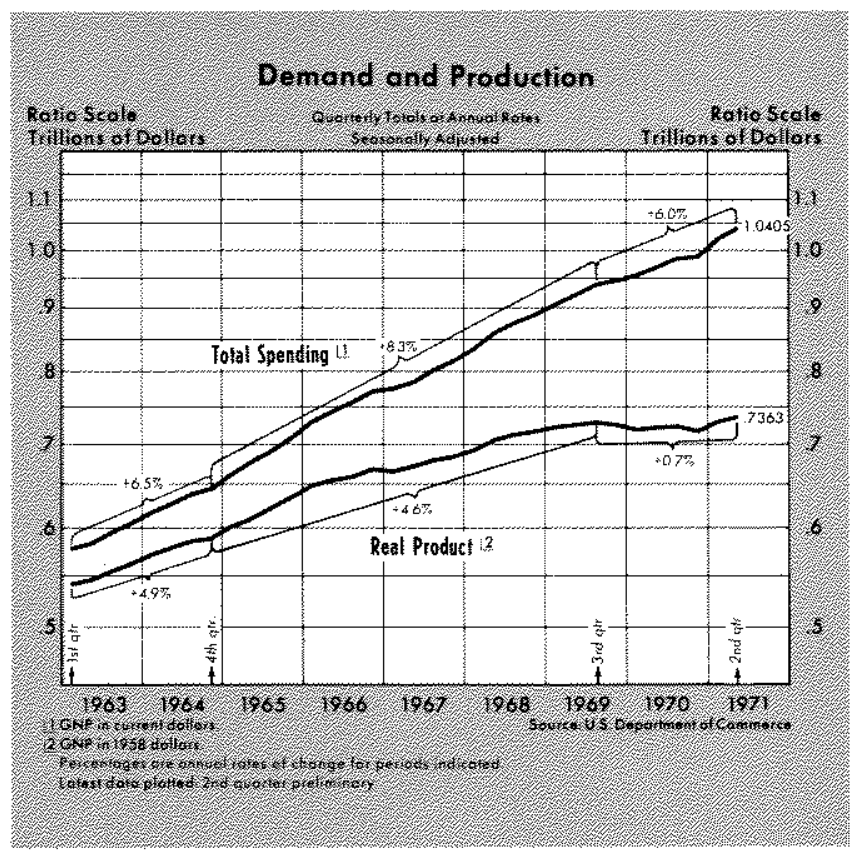

1The business slowdown probably continued into the fourth quarter of last year, but the concurrent strike in the automotive industry distorts the fourth quarter data. For this reason, the third quarter of 1970 is used here for a benchmark. This procedure reduces the effects on the data of the strike and subsequent adjustment in the first quarter of this year. 
Rapid income growth has facilitated increased personal consumption expenditure, despite historically high saving rates on the part of individuals. Spending for consumption goods rose at an 8.5 per cent annual rate from the third quarter of last year, following a 6.3 per cent rise in the previous year. Saving averaged slightly more than 8 per cent of after-tax income in the past year, compared to an average of about 6 per cent in the last decade. Disposable income rose at an 8.7 per cent annual rate over the last three quarters.

\section{Emplotment and Prices}

The renewed growth of total spending has not had a noticeable stimulative effect on employment; the level of total civilian employment in July was about the same as it was early in the year. Contrary to other periods of economic slowdown, however, employment did not decline significantly during the slowdown last year. Unemployment averaged 6 per cent of the labor force in the second quarter, about the same as in the previous two quarters.

The level of prices, as measured by the GNP deflator, increased at a 5.2 per cent annual rate in the last three quarters, about the same rate of increase experienced in the previous year. This marks the first sustained period since 1965 when the rate of price change did not accelerate. The rate of increase of consumer prices has moderated somewhat, with these prices rising 4.5 per cent in the last year compared with a 6 per cent increase from mid-1969 to mid-1970.

\section{Interest Rates and Money}

Interest rates in July were below their peaks of 1970 , but have risen on balance since early this year. The market yield on three-month Treasury bills averaged 5.40 per cent in July, compared with a low of 3.38 per cent in March. The bill yield had reached a monthly average high of 7.87 per cent early in 1970 . Interest rates on longer-term securities have followed the same general pattern but have shown much less variation. Yields on seasoned high-grade corporate bonds, for example, averaged 7.64 per cent in July, up from 7.08 per cent in February of this year, but below the high of 8.48 per cent in June 1970 .

The money stock increased at a rapid 12 per cent annual rate from January to July, following a 4.7 per cent rise in the previous year. The increase in the money stock reflected expansion of the demand deposit component of money, which rose at a 13 per cent rate from January to July, after increasing 4 per cent in the year prior. The accelerated growth of

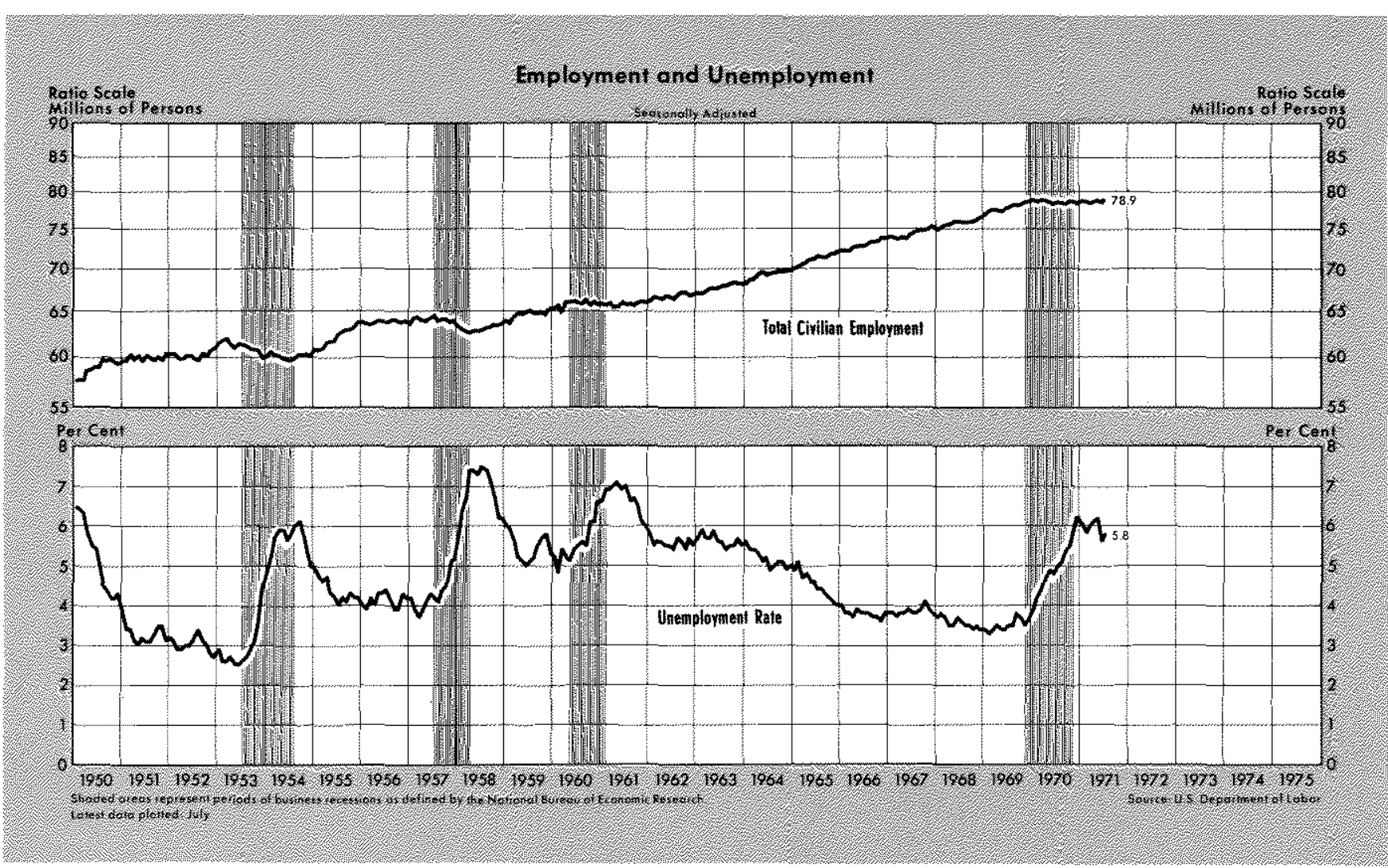




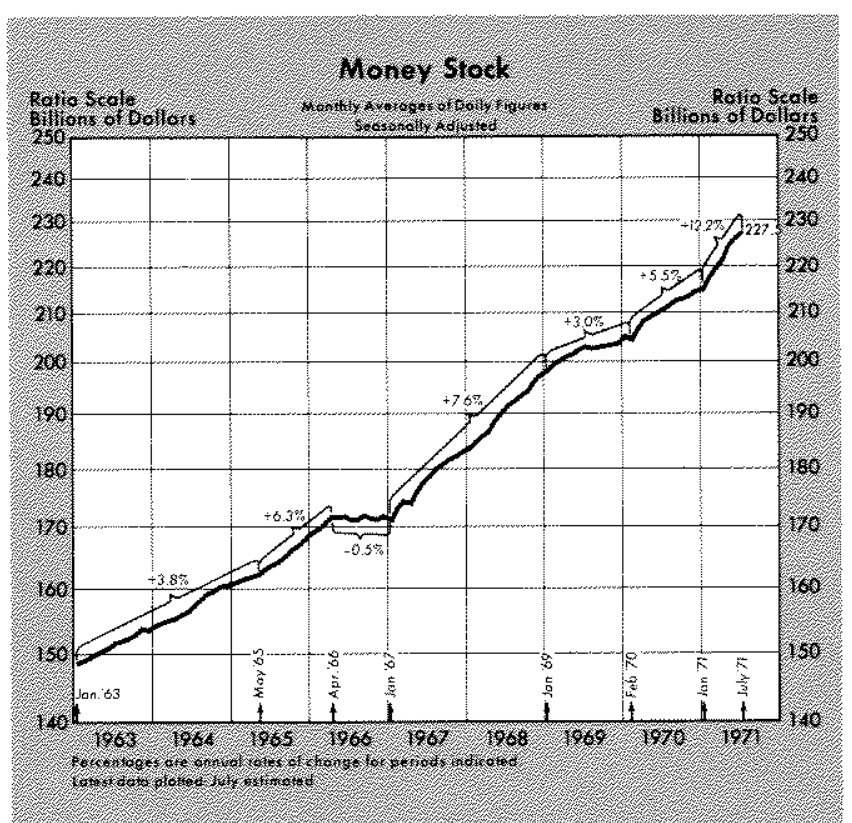

demand deposits was fostered by rapid expansion of reserve aggregates this year. The monetary base, the growth of which is dominated by Federal Reserve actions, has increased at a 10 per cent rate since January. In contrast, the base rose 6.2 per cent in 1970 .

\section{Inflation and Interest Rates}

While the excessive growth of aggregate demand was sharply reduced in 1970 , the reduced expansion of total spending in this period served only to halt the acceleration of the inflation. Prices have risen at about the same rate since early in 1969 . Most of the immediate effect of the moderation of total spending growth fell on the growth rate of output and employment. The result to date has been simultaneous rapid inflation and relatively high rates of unemployment, a situation not previously experienced in the postwar period.

\section{Developing Inflaton: $1965-69$}

The pressures of excessive demand to which the economy was subjected in the 1965-69 period were severe. The effects of these pressures are apparently long-lasting, as evidenced by the economic situation in 1971 .

After six years of moderate but steady growth, the economy reached full-employment in 1965. Prices were rising at a 1.6 per cent rate and the economy was apparently operating smoothly. With the beginning of the Vietnam buildup in 1965, however, stresses developed quickly. Federal budget expenditures for both defense and nondefense programs accelerated sharply and the budget deficit grew progressively larger, reaching a total in excess of $\$ 25$ billion in fiscal 1968. Federal borrowing to finance these deficits added to already buoyant private demands for credit which emanated from the full-employment economy. These strong demands for credit, and resultant upward pressures on interest rates, led to rapid monetary expansion, especially following the brief "creditcrunch" period in 1966 and resulting economic slowdown early in $1967 .^{2}$

From early 1967 to early 1969, the money stock increased at a 7.6 per cent annual rate, generally reflecting Federal Reserve attempts to counter the upward pressure on interest rates. The upward trend of interest rates was associated with the acceleration of inflation, strong private credit demand and the large Government borrowing. During this period Federal Reserve holdings of Government securities increased at a 9.3 per cent annual rate and the monetary base increased at a 6.4 per cent rate. In comparison, the base had expanded at an average 4.3 per cent rate from 1961-65.

Growth of total spending accelerated in response to the stimulative monetary and fiscal actions. Spending grew at an 8.1 per cent annual rate from early 1965 to mid-1969, compared with the 7 per cent rise experienced on average during the 1961-65 period. Since productive capacity in the fully employed economy was increasing about 4 per cent per year, the accelerating pace of spending put increasing upward pressure on prices. After rising at a trend rate of 1.6 per cent annually in the early $1960^{\prime}$ 's, prices rose at an average 3 per cent rate from mid-1965 to mid-1967, a 4 per cent rate over the next year, and then at almost a 5 per cent rate to mid-1969. In four years, the rate of price increase had more than tripled, and apparently became a major factor in economic decision-making.

As the growth of total spending began to slow in late 1969, inflationary expectations were still gaining momentum. Consequently, wage contracts and sales agreements were being negotiated on the basis of continuing inflation. Prices, therefore, continued to rise rapidly in 1970 despite moderation in growth of total demand induced by monetary and fiscal actions. Given the momentum of inflation, the slowdown in total spending was manifested in slowdown of output and employment.

\footnotetext{
2For a review of the effects of Treasury financing on monetary policy actions during the 1967-68 period see: "1967 A Year of Constraints on Monetary Management," this Revietw (May 1968), pp. 6-20; and "Federal Open Market Committee Decisions in 1968 - A Year of Watchful Waiting," this Review (May 1969), pp. 6-15.
} 


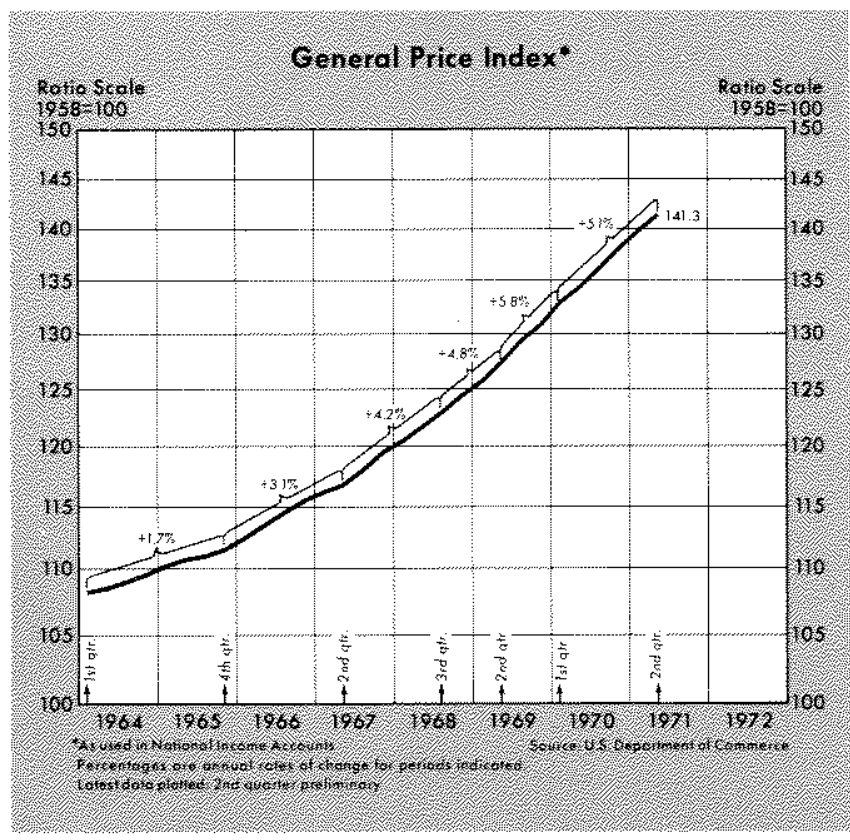

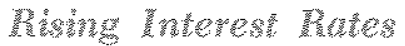

The effects of inflation on economic activity vary with the degree to which the price increases are anticipated..$^{3}$ For example, an unanticipated increase in the price of goods and services results in a redistribution of real wealth from net creditors to net debtors. People who hold their wealth in the form of money or any other fixed-dollar-donominated assets experience a net decline in real wealth as the purchasing power of each dollar falls. Those economic units who borrow prior to the price increase repay their loans in dollars which command less goods and services than when the loan was contracted.

Interest rates reflect the interaction of business sales expectations, the productivity of capital (including human capital), and the preference of individuals for current consumption versus the possibility of future consumption (that is, the willingness to save). Following an unexpected change in the price of commodities, creditors become reluctant to lend funds at the then current rate of interest. After experiencing an unexpected net decline in their wealth, creditors become less certain that prices will not rise again. They attempt to protect the real value of their wealth by increasing their lending charges (interest), to compensate for the possibility of another increase in the price of commodities (decrease in the purchasing power of cash). To the extent that borrowers expect the price

\footnotetext{
SSee A. A. Alchian and W. R. Allen, University Economics, 2d ed. (Belmont, Califomia: Wadsworth Publishing Company, inc, 1968), pp. 426-38, 647-68.
}

level to rise, they anticipate repaying any loans with depreciated dollars. Thus, the real demand for credit increases. The net result is upward pressure on market interest rates. Interest rates tend to continue rising until the rate of inflation becomes constant and fully anticipated. In this context, rising interest rates are a symptom of inflation.

The speed at which price anticipations, and thus interest rates, adjust to observed price changes is an unresolved question. There is evidence to suggest, however, that these expectations were much more Hexible in the late $1960^{\text {'s }}$ than they had been previously. As a consequence, much of the rise in market interest rates from 1965 to 1969 was probably due to growing anticipation of inflation.

\section{Interest Rates and Economic Activity in 1971}

Some economic analysts, concerned with increasing the level of employment in the current expansion, have suggested that sharp increases in interest rates could slow the growth of economic activity. ${ }^{\text {s }}$ They argue that capital expenditures provide the basis for economic expansion, and that rising interest rates, especially in the long-term market, increase the cost of borrowing and may "choke off" the private spending required to restore full employment.

This analysis is incomplete, however, in that it considers only the supply of credit as a factor affecting market interest rates. This reasoning implies that rising interest rates signal a restriction of credit supply and a reduced growth of credit extended. It ignores the effect of credit demand on interest rates.

Problems of interpreting interest rate movements often involve determining whether these rates reflect the effeots of current stabilization actions or the lagged effects of past actions. The specific problem is that the short-run effect of stabilization actions on the supply of credit may be quite different from the longer-

\footnotetext{
"See "Interest Rates and Price Level Changes, 1952-69," this Review (December 1969), pp. 18-38; and Martin Feldstein and Otto Eckstein, "The Fundamental Determinants of the Interest Rate," Review of Economics and Statistics (November 1970), pp. 363-375.

For examples of analysis which assigns an important role to interest rates in affecting the pace of economic activity, see the testimony of Arthur Okun, Otto Eckstein and Robert Eisner, Hearings before the Joint Economic Committee, Congress of the United States, on The 1971 Economic Report of the President, Part 2, February 23 and 24, 1971, (Washington, D. C.: U. S. Government Printing Office, 1971).
} 


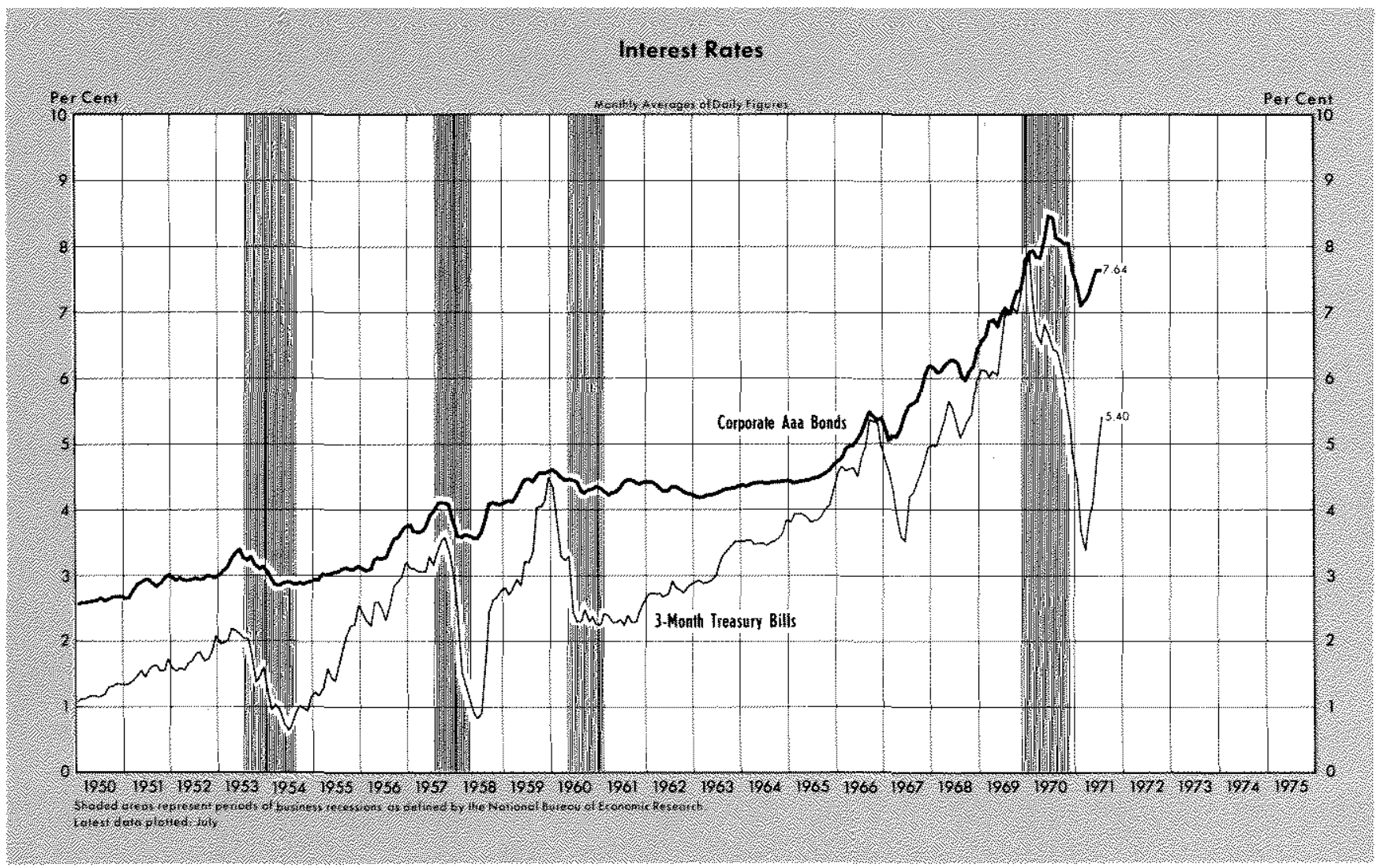

run effect which includes both supply and demand factors.

Although accelerated monetary expansion adds to the supply of loan funds, the immediate tendency of such action to reduce interest rates is often overwhelmed by other effects. ${ }^{6}$ If the supply of money and credit expand rapidly, given existing income, stocks of assets and interest rates, people attempt to dispose of excess money balances. They try to exchange cash for goods, services, and other assets. The increase in the demand for goods and services will then stimulate business sales expectations and induce expansion of credit demands to finance new production or inventories. If this effect takes a relatively short time to get underway, the increased supply of credit could be accompanied by an increase in demand for loan funds sufficient to raise the rate of interest. In addition, should the increase in aggregate demand result in increased prices, the stimulation of inflation expectations would put further upward pressure on interest rates. This analysis leads to the conclusion, for example, that the sharp rise in interest rates from 1967 to 1969 reflects the effects of accelerated monetary expansion which stimulated demands for credit.

\footnotetext{
"See "A Monetarist Model for Economic Stabilization," this Review (April 1970), pp. 7-25.
}

The decline in rates during late 1970 and early 1971 probably reflected a general easing of credit demands in response to slower monetary growth in 1969. Also, the rapid monetary expansion which began early this year probably had a depressive effect on interest rates during the first few months of this year.

It is difficult to attribute the rise in interest rates this year to restriction of the supply of credit. As evidenced by the rapid monetary expansion, the Federal Reserve has supplied considerable funds to the market. Total deposits at commerical banks plus nonbank thrift institutions have increased substantially this year, rising at an estimated 17 per cent annual rate since January, following a 12 per cent increase in the previous year. With an apparently rapid expansion of credit supply, explanation for the upward movement in interest rates must lie with the demand for credit.

Corporations, apparently seeking to improve their liquidity, engaged in long-term borrowing in the first half of this year. Government borrowing requirements were substantial in the second quarter and are expected to remain strong for some time. The Federal budget is now expected to be in deficit by at least $\$ 20$ billion in the current fiscal year, following a deficit of $\$ 23.2$ billion in the fiscal year ended in June. 
In analyzing the predictable effect of rising interest rates on the future pace of economic activity, it is difficult to ignore the potentially stimulative effect of the rapid rate of monetary expansion over the first seven months of this year. Historically, it has been observed that aggregate demand responds to changes in the rate of monetary expansion within six to nine months. This suggests that the main effect on private spending of the recent accelerated growth of money is yet to be realized. Private credit demands would then tend to increase, putting further upward pressure on interest rates. Rising interest rates, instead of choking off private demand, would actually indicate a more rapid rate of economic expansion.

While rising interest rates are not necessarily indicative of restraint on total spending in the economy, they often indicate restriction on individual sectors. Interest rates serve to ration credit, allocating available funds to the various sectors of the economy. Thus expansion of the amount of credit supplied does not imply that all sectors in the economy will be able to obtain more credit.

Due to existing legal constraints on the maximum interest rates that savings institutions can pay on deposits, for example, rising interest rates may result in renewed disintermediation of funds. This would tend to restrict the supply of funds into the mortgage market as in the 1967-69 period. The reintermediation of funds which accompanied the general decline in interest rates last year has been a major factor contributing to expansion of residential construction over the last year. Other sectors of the economy are similarly affected by legal institutions and constraints. State and local governments are often restricted by law in the maximum interest rate they can pay for borrowed funds. In the past, rising interest rates have contributed to sharp curtailment of this government borrowing.

It is fallacious to assume, however, that total demand will necessarily be reduced by rising interest rates. When increases in interest rates restult from expansion of credit demand, as they have recently, the composition of credit may change, but total credit extended will tend to rise.

\section{Summary}

The recent pattern of interest rates is not indicative of monetary restraint, and thus does not signal a slow economic expansion. It does suggest that total demands for credit (private and government), reinforced by inflationary expectations, remain strong. Even though the rate of resource utilization is below optimal levels, there are dangers of creating momentum which might bring about renewed acceleration of inflation. As reflected in recent interest rate movements, market actions already may be based on such anticipations. Market developments in recent months could indicate a lack of confidence in the ability of stabilization authorities to effectively reduce the rate of inflation.

An adjustment to the excessive expansion of total demand in 1965-69 is underway. The adjustment has been slow, but, given the momentum and severity of the inflation in the late 1960 s, it is difficult to see how the correction could have been accelerated. Further stimulation of total demand to quicken the adjustment in employment and production would rekindle inflationary pressures.

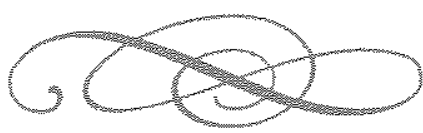

